\title{
Annual variation of rainfall over Brazil and water vapor characteristics over South America
}

\author{
Vadlamudi Brahmananda Rao, Iracema F. A. Cavalcanti, and Kioshi Hada \\ Instituto Nacional de Pesquisas Espaciais, São José dos Campos, Sao Paulo, Brazil
}

\begin{abstract}
A large region in central Brazil is characterized by summer rainfall and winter dry conditions. During the 6-month period of September, October, November, December, January, and February (SONDJF) this region receives $70 \%$ or more of its annual rainfall. Calculations of vertically integrated water vapor flux and its divergence are made for South America. The results suggest that the Amazon basin is the principal source of moisture for central Brazil during the period SONDJF. Water vapor flux from the equatorial Atlantic associated with trade winds is the main moisture source for the Amazon basin.
\end{abstract}

\section{Introduction}

Tropical South America is characterized by strong annual variation of rainfall with heavy rainfall in austral summer and scanty rainfall in austral winter. This annual variation in rainfall is linked to the annual variation of atmospheric circulation over South America. The limited number of rawinsonde stations prevented a good description of circulation characteristics. Some studies have, nevertheless, been made describing monthly and seasonal features. On the basis of data collected in the late 1960s, Kreuels et al. [1975] examined the circulation patterns over South America in summer and winter. Virji [1981] deduced the summertime circulation patterns from cloud motion vectors. However, his study was based on only 3 years (1975-1977) of data.

Chu [1985] used radio/rawinsonde data for the period 19701974 to study the atmospheric circulation characteristics over tropical South America. Although he used an objective analysis method to obtain interpolated data at regular grid points, his basic data were rawinsonde data only. In the present study we used objectively analyzed European Centre for MediumRange Weather Forecasts (ECMWF) data which contain satellite estimates of wind and temperature in addition to radio/ rawinsonde data. Further, these data are dynamically consistent [Bengtsson et al., 1982], unlike the data taken directly from radio/rawinsonde observations.

Nishizawa and Tanaka [1983] related the annual cycle of circulation over tropical South America to that of rainfall. Their database consisted of upper air soundings for a 10-year period (1969-1978) together with monthly averages of rainfall. They presented a climatology of annual cycle in terms of a series of monthly maps. Although they inferred the role of atmospheric circulation in the transport of water vapor, they did not make an explicit calculation of water vapor transport to confirm their conjectures.

The above mentioned studies brought out the characteristics of summer circulation over South America. The principal features are a closed anticyclone over Bolivia known as Bolivian High and a downstream trough located to the east of it.

In a recent study, Horel et al. [1989] documented the annual Copyright 1996 by the American Geophysical Union.

Paper number 96JD01936. 0148-0227/96/96JD-01936\$09.00 cycle of convective activity and circulation pattern over South America. They used outgoing longwave radiation (OLR) data to describe the annual cycle of convection. Wind analysis produced by ECMWF were superimposed upon OLR fields to illustrate features of atmospheric circulation in the vicinity of tropical America that were associated with the annual cycle of convection. They found that the Bolivian High develops rapidly during the beginning of the transition to summer in a way that is consistent with the distribution of OLR. The purpose of the present study is to examine the annual variation of rainfall over Brazil and atmospheric circulation over South America. It is different from that of Horel et al. [1989] in that we make use of different data sets and give new interpretation to the characteristics of the seasonal cycle over South America. In particular, we study the role of water vapor flux in the annual variation of rainfall. The subject of the paper, that is, the relationship between the annual cycle in rainfall and the annual cycle in atmospheric circulation, is important since most general circulation models have a difficult time in correctly simulating tropical circulation and precipitation patterns. Thus the present work could be used as a basis for validating model simulations and perhaps as a result lead to model improvements.

\section{Data Sources and Method of Analysis}

To depict the annual variation of rainfall over Brazil, we used the same network of rain gauge stations as in a previous study [Rao and Hada, 1990]. Figure 1 of Rao and Hada [1990] gives the station location. As in the previous study we used the rainfall data for the period 1958 through 1978. We also used the surface dew point temperature data for Brasilia $\left(15^{\circ} 51^{\prime} \mathrm{S}\right.$, $\left.47^{\circ} 56^{\prime} \mathrm{W}\right)$ and Manaus $\left(3^{\circ} 8^{\prime} \mathrm{S}, 60^{\circ} 1^{\prime} \mathrm{W}\right)$. These data were provided by the Departamento Nacional de Meteorologia of Brazil. To discuss the atmospheric circulation over South America, we used the ECMWF data for the period 1985 through 1989 at 1200 UTC. The specific humidity $q$ values are obtained using the relative humidity $r h$ of the ECMWF data and the saturated vapor pressure $e_{s}$ calculated from the Clausius-Clapcyron equation.

The ECMWF analyses have undergone significant changes. Of greatest impact upon the tropical circulation are the introduction of diabatic linear normal mode initialization in September 1982 and implementation of a diurnal cycle of radiation 
in 1984. Thus the data we used here for the 5-year period, 1985-1989, are considered to be better than the data of earlier years. For further information see Trenberth and Olson [1988]. The ECMWF data are archived upon a $2.5^{\circ} \times 2.5^{\circ}$ grid. Data at seven levels $(1000,850,700,500,300,200$, and $10 \mathrm{hPa})$ and of five variables (height, temperature, relative humidity, horizontal wind, and vertical motion) are available.

Precipitable water $P W$ is calculated using $q$ values.

$$
P W=\frac{1}{g} \int_{P_{\mathrm{t}}}^{P_{0}} q d p
$$

$P_{t}=300$ mbar, $P_{0}=1000 \mathrm{mbar}$, and $g$ is the acceleration of gravity.

Vertically integrated water vapor flux is calculated from

$$
Q=\frac{1}{g} \int_{P_{t}}^{P_{0}} \vec{q} \overrightarrow{\mathbf{v}} d p
$$

where $\mathbf{v}$ is the horizontal vector wind. The integrals in (1) and (2) are evaluated using data at 1000-, 850-, 700-, 500-, and $300-\mathrm{hPa}$ levels. These levels are adequate for the calculation of water vapor flux because water vapor is mostly concentrated at the lower levels.

Equation (2) is further divided as

$$
Q=Q_{M}+Q_{E}
$$

where

$$
\begin{gathered}
Q_{M}=\frac{1}{g} \int_{P_{t}}^{P_{0}} \bar{q} \overline{\mathbf{v}} d P \\
Q_{E}=\frac{1}{g} \int_{P_{t}}^{P_{0}} \overline{q^{\prime} \mathbf{v}^{\prime}} d P
\end{gathered}
$$

In (3) the overbar represents time mean of 1 month and a prime represents deviation from mean. As mentioned earlier, 5 years (1985-1989) of data have been used to evaluate (2) and (3). The $Q_{M}$ represents the water vapor transport by the mean motion and the $Q_{E}$ represents the water vapor transport by the transient eddies.

Before starting to discuss the results, some comments about the possible errors are in order. The derived water vapor flux, particularly its divergence, may be compromised by error in the original data and truncation error in the finite difference scheme (to calculate the divergence). Discussion of errors by Ward and Smith [1976] and Fuelberg and Scoggins [1980] suggest that the calculation of water vapor flux is substantially more reliable than the divergence term. Using a method similar to that of Ward and Smith [1976] and Fuelberg and Scoggins [1980] and using the probable errors in the direction and speed of the wind furnished by Kurihara [1961], Marques et al. [1983] found that the errors in the calculation of divergence (in their case normal velocity) were small (around $13 \%$ at surface, 900 and $800-\mathrm{hPa}$ levels) below the 400 -hPa level. Details of error analysis were given by Marques [1981]. Since water vapor is concentrated below the $400-\mathrm{hPa}$ level, calculation of water vapor flux divergence might be reasonably reliable.

\section{Results}

In this section we present results concerning the annual variation of rainfall over Brazil and atmospheric circulation over South America. We start with the discussion of seasonal distribution of rainfall in relation to the annual rainfall.

\subsection{Annual Variation of Rainfall Over Brazil}

Figure 1a shows the isolines of percentage contribution of the rainfall for the 3-month period December, January, and February (DJF) to the annual rainfall. Similarly, Figures 1b, 1c, and $1 \mathrm{~d}$ show the percentage contribution of March, April, and May (MAM), June, July, and August (JJA), and September, October, and November (SON), respectively, to the annual rainfall. Figures 1a-1d were prepared in the following way. At each station the mean (1958-1978) annual rainfall is calculated. Then the percentage contribution of each 3-month period to the annual total is calculated, and isolines of percentage contribution for each 3-month period are drawn.

Several interesting features are evident in Figures 1a-1d. In southern Brazil, rainfall is almost uniformly distributed in all the four seasons, with a contribution of around $25 \%$ in each of the 3-month periods. To the north of this region there is a large area over which the percentage in DJF is around $45 \%$ or more. In SON the percentage contribution is around $25 \%$ or more. During the 6-month austral summer period of SON and DJF the percentage contribution to the annual rainfall is $70 \%$ or more. Thus during the remaining 6-month winter period the rainfall is $30 \%$ or less of the annual total. This region has an annual rainfall distribution such that summer is rainy and the winter is dry. As will be seen later, the change from winter to summer happens through a sudden change in the atmospheric humidity characteristics.

To the northwest of this region the rainfall again is uniformly distributed throughout the year. As will be seen later, this region, represented by the Manaus station, is characterized by uniformly high humidity without much seasonal variation.

In the northern parts of northeast (NE) Brazil the principal rainy season is MAM [Strang, 1972; Hastenrath and Heller, 1977; Rao and Hada, 1990]. It can be seen in Figure 1b that more than $40 \%$ of the annual rainfall in this region occurs in MAM. During the 6-month period of DJF and MAM (Figures 1a and $1 \mathrm{~b}$ ) more than $80 \%$ of the annual rainfall occurs in this region with only $20 \%$ distributed during the remaining 6 months. The coastal region of eastern northeast (NE) Brazil is characterized by winter rainfall [Rao et al., 1993]. As can be seen in Figure 1c, there is a narrow region in the eastern part of coastal NE Brazil in which $40 \%$ of the annual rainfall occurs during the 3-month period of MAM. The 6-month period of MAM and JJA, accounts for as much as $75 \%$ of annual rainfall in this region.

In summary, on the basis of the present analysis, Brazil can be divided approximately into five regions: 1, southern Brazil with well-distributed rainfall throughout the year; 2 , a large central region with a wet summer and dry winter regime; 3 , a northwest region in which the rainfall is well distributed throughout the year; 4, northern NE Brazil with rainfall season in MAM; and 5, eastern NE Brazil with the principal rainy season in winter.

\subsection{Surface Dew Point Temperatures}

Figure 2 shows daily values of the surface dew point (in degrees Celsius) at Brasilia at 1200 UTC. The smoothed line is the running mean for 11 days. The crosses below each dew point value denote the occurrence of precipitation at Brasilia. The horizontal line is the yearly mean value. Note that there is a rapid transition from dry conditions up to the end of Sep- 


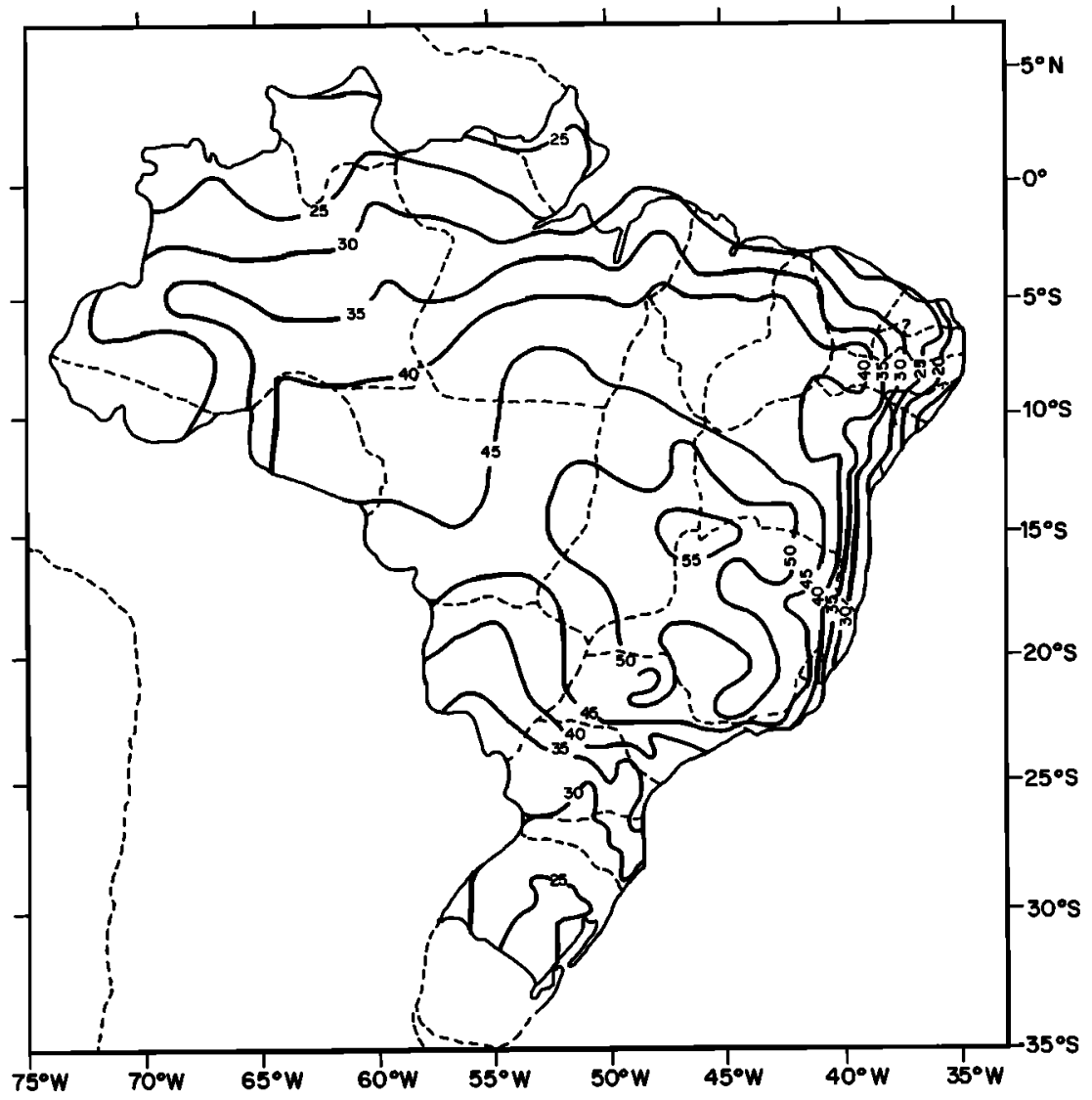

Figure 1a. Percentage contribution of December, January, and February rainfall to the annual rainfall.

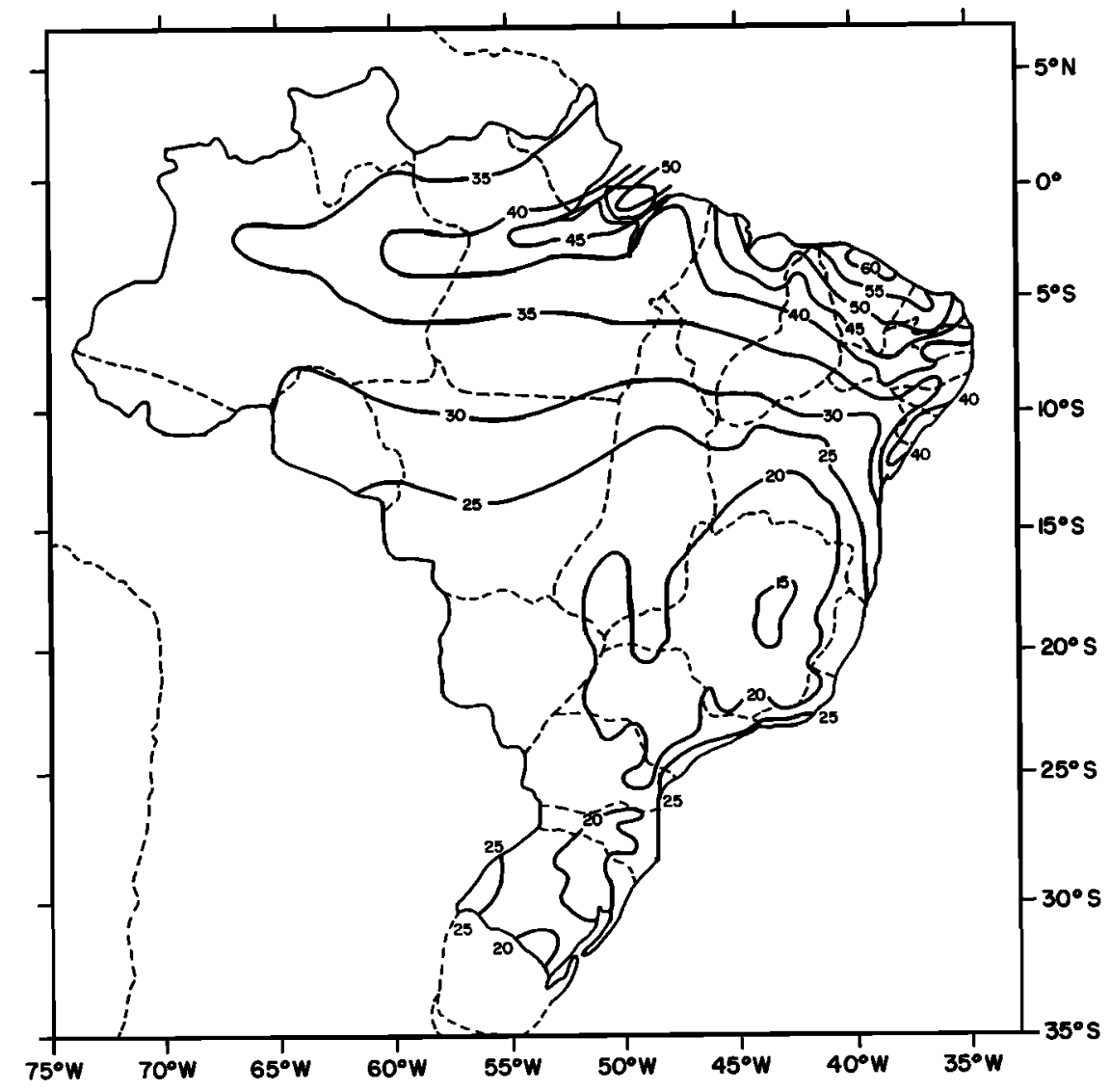

Figure 1b. Same as Figure 1a but for March, April, and May. 


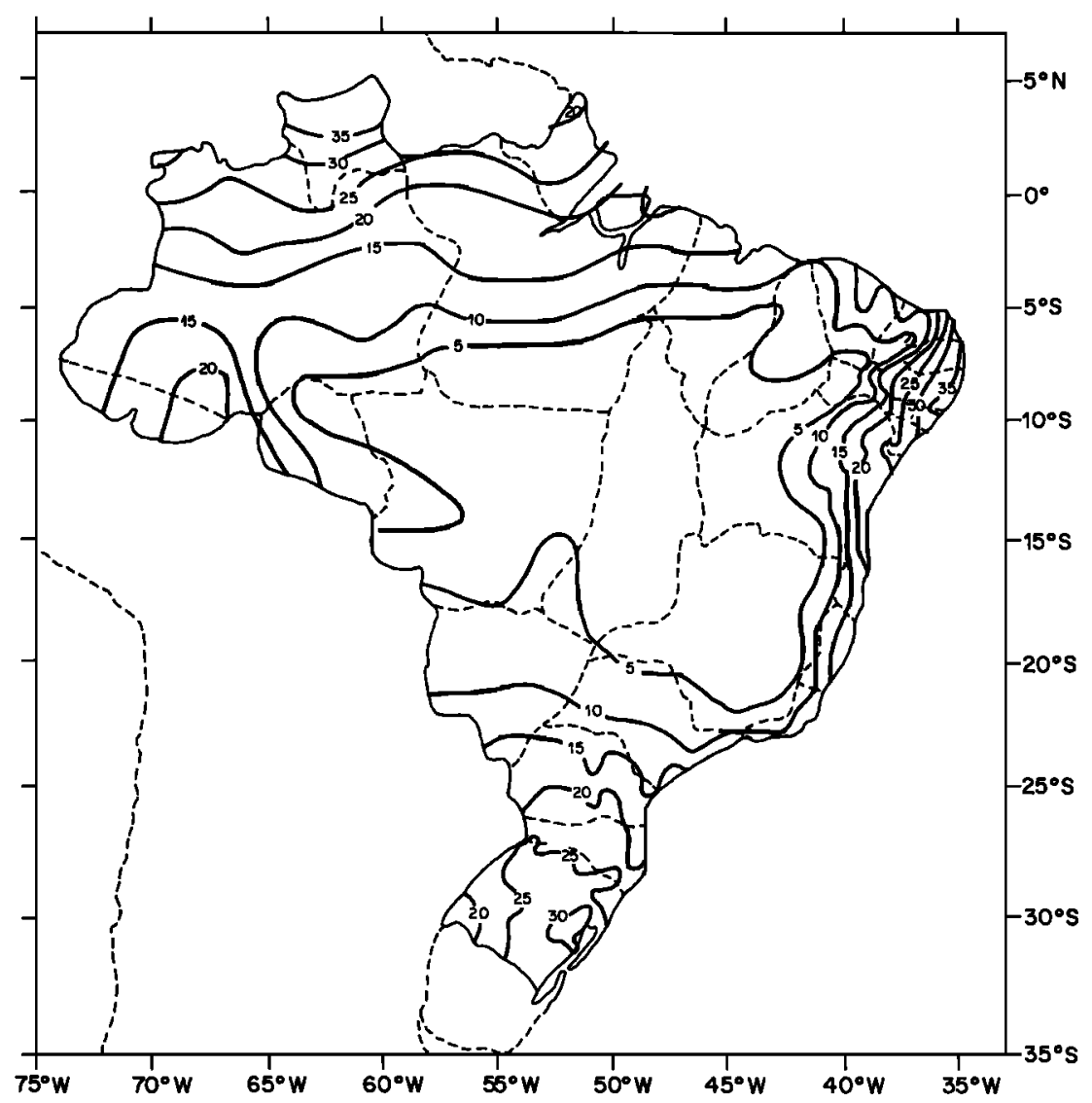

Figure 1c. Same as Figure 1a but for June, July, and August.

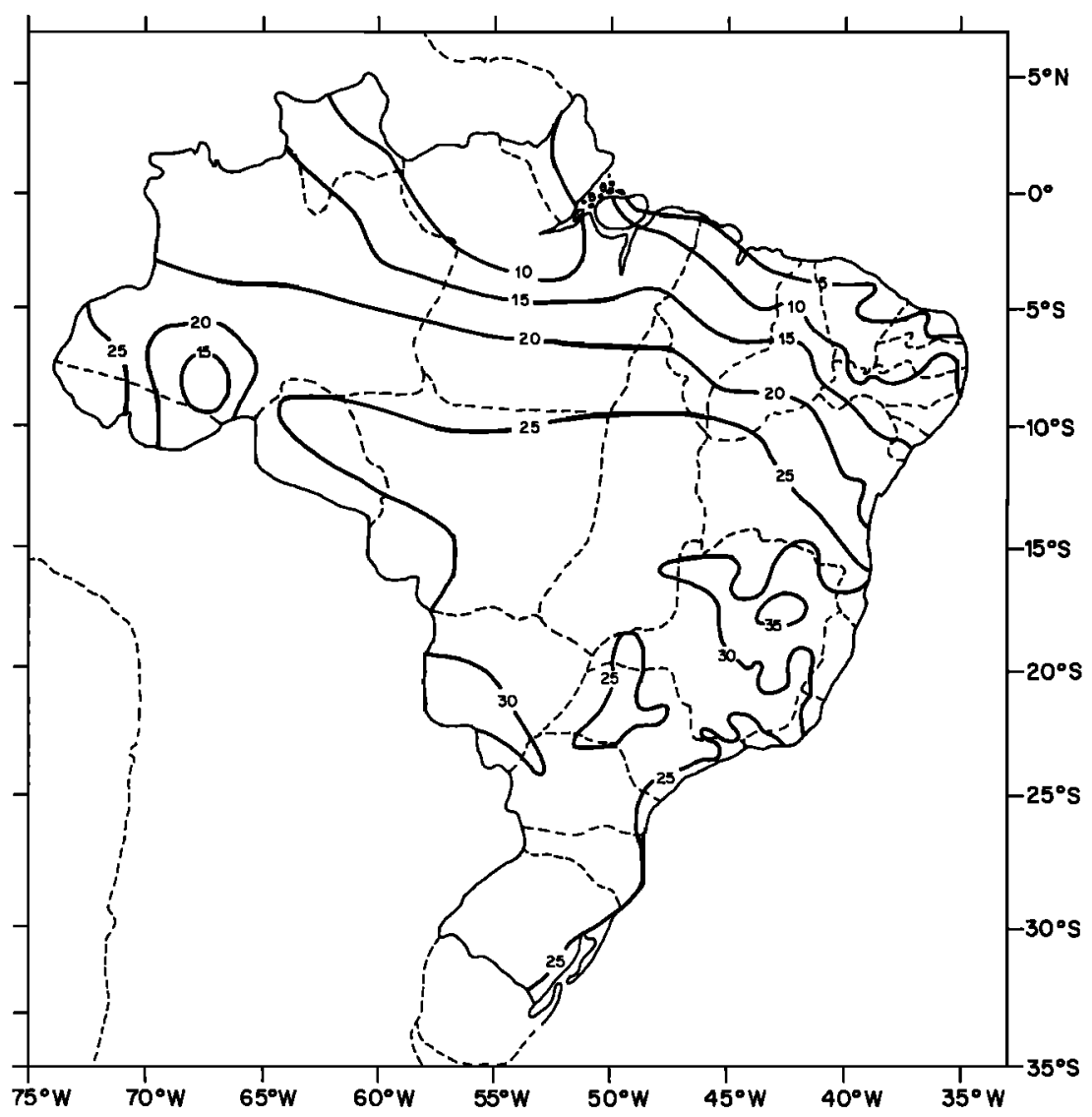

Figure 1d. Same as Figure 1a but for September, October, and November. 

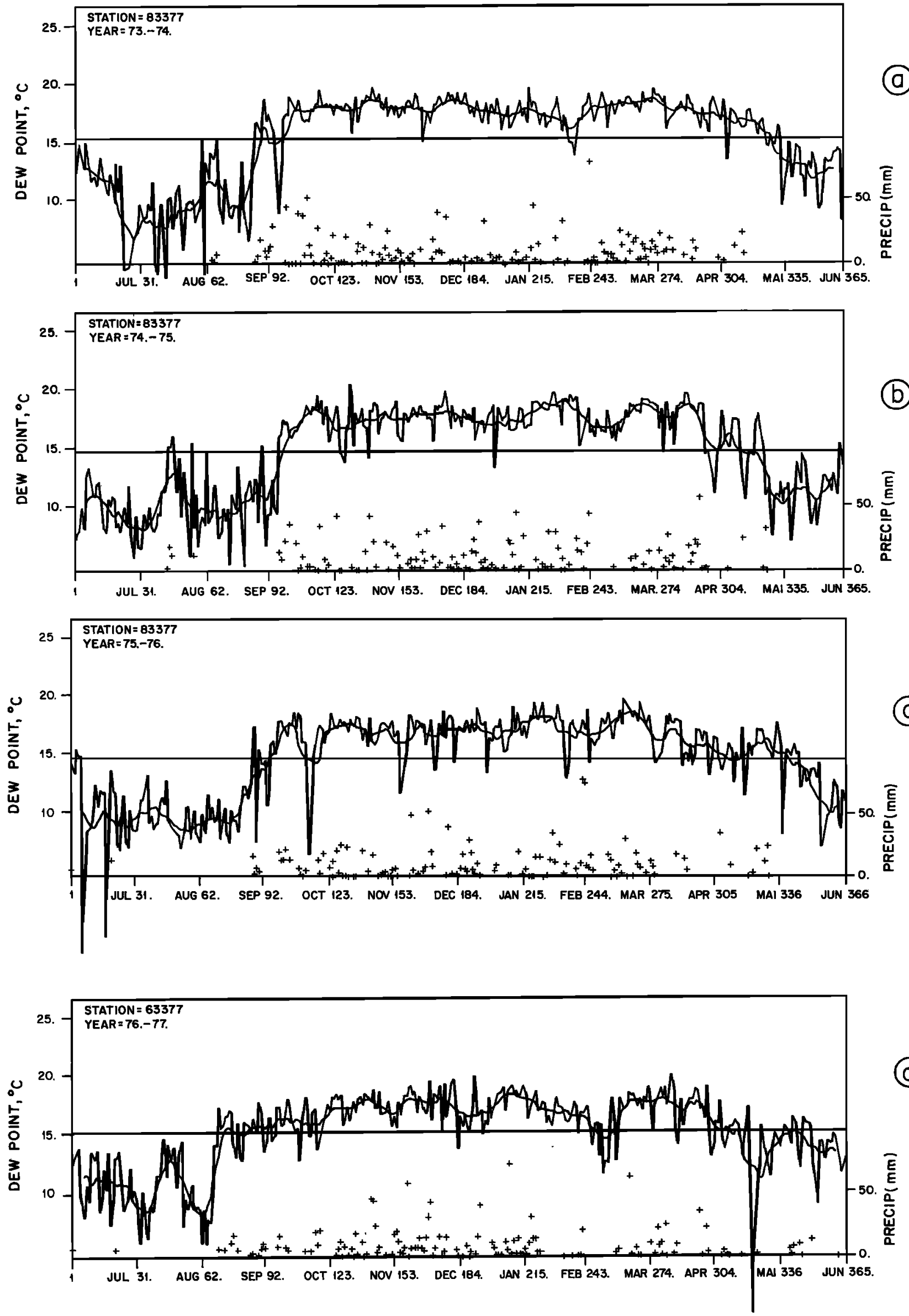

Figure 2. Surface dew point (in degrees Celsius) variations over Brasilia: (a) 1973-1974, (b) 1974-1975, (c) 1975-1976, and (d) 1976-1977. Crosses indicate occurrence of rainfall. 
tember to a wet air mass in which precipitation is frequent. The wet conditions remain up to the end of April, and then there is a gradual return to dry conditions. These features are consistent with the OLR climatologies [Horel et al., 1989; Kousky, 1988]. There are interannual variations in the onset and withdrawal of wet conditions. Periods of drying after initial transition to wet air mass are also evident in Figure 2 (October 1975).

In order to see how the variations of dew points are in the northwest region, we plotted the dew points at Manaus (Figure 3 ). The characteristics of Figure 3 are very different from those shown at Brasilia (Figure 2). As expected, the yearly average value at Manaus is much higher than the yearly average value at Brasilia. Unlike what is seen over Brasilia, there is no clear indication of dry and wet periods, except for a slight decrease of dew points and rainfall in July and August.

From the analysis of dew point temperatures it can be inferred that the central parts of Brazil represented by Brasilia have a clear variation of atmospheric regime with a dry epoch without much rainfall from April through September and a wet period characterized by high humidity and rainfall during the remaining months of the year. What features of atmospheric circulation are responsible for the change from the dry period at Brasilia to the wet period? In section 3.3 we shall discuss the annual variation of atmospheric circulation over South America.

\subsection{Atmospheric Circulation Over South America at 850 mbar}

Figure 4 shows the streamlines and isotachs at $850 \mathrm{mbar}$ for January, April, July, and October. These are based on 5 years (1985-1989) of ECMWF data. Surface humidity, as given by dew points, is closely related to the variations in $850 \mathrm{mbar}$ circulations. Atmospheric circulation at 850 mbar over South America throughout the year is dominated by the subtropical anticyclones in the Pacific and Atlantic. During the austral winter (July) the Atlantic subtropical anticyclone penetrates the continent more than in summer (January), and the flow is mostly zonal.

Another feature worth noting in January is the indication of a closed cyclonic circulation over South America in the subtropics around $70^{\circ} \mathrm{W}$. As we shall see later, this cyclonic circulation is associated with an anticyclonic circulation (Bolivian High) at 200 mbar.

What aspect of atmospheric flow is responsible for the humidity variations noted in Figure 2? A careful examination of Figure 4 shows that during the summer the flow is mostly meridional over the central parts of Brazil. This southward flow coming from the Amazon region seems to be responsible for the higher humidity during the summer beginning around October. An actual calculation of water vapor flux discussed later shows that this, indeed, is the case.

Figure 5 shows the distribution of isotherms (in kelvins) at 850 mbar for January, April, July, and October. As can be expected, seasonal temperature variations are small over northern parts of South America, except for a slight decrease of temperature in austral winter, July. Seasonal temperature variations are stronger over southern parts of South America, and we can note stronger meridional temperature gradients in winter (note the differences in the contour intervals in Figures $5 \mathrm{a}, 5 \mathrm{~b}, 5 \mathrm{c}$, and $5 \mathrm{~d})$.

\subsection{Atmospheric Circulation Over South America at 200 mbar}

Figure 6 shows the streamlines and isotachs over South America at the 200-mbar level for January, April, July, and October. In the beginning of the year (January) we can clearly see the anticyclone over Bolivia (Bolivian High) and a trough over NE Brazil. These are well known features of the summer circulation and were discussed by Virji [1981]. As the season advances, the flow becomes mostly zonal over much of South America. In October the anticyclone over Bolivia and the trough over NE Brazil begin to develop.

Figure 7 shows the distribution of temperature (in kelvins) at 200 mbar for January, April, July, and October. Again, temperature variations are stronger in the southern latitudes. In January, temperature is lowest in the subtropics and increases both poleward and equatorward. Similar characteristics are found in April. In July, temperature decreases from the subtropics toward higher latitudes. Similar characteristics are found in October. These are some of the well-known features of the upper atmosphere in middle and higher latitudes.

\subsection{Water Vapor Characteristics}

Figure 8 shows the precipitable water $\left(\mathrm{kg} \mathrm{m}^{-2}\right)$ calculated using (1). These values can be compared with those obtained earlier by Viswanadham et al. [1980] and Chen [1985]. A careful examination of Figure 3 of Chen [1985] for the South American region shows a good agreement both in magnitude and general characteristics of precipitable water. Chen's values were consistent with earlier computations. This gives confidence to the calculation of water vapor characteristics using ECMWF data. In our results more details over South America are given for the four seasons. One important feature of the summer circulation in the South American region is a zone of convergence and intense convection oriented northwest to southeast in the subtropics near the coast of southeast Brazil projecting into the adjoining South Atlantic Ocean, known as the South Atlantic Convergence Zone (SACZ) [Kodama, 1992]. A higher water vapor content is expected over the regions of intense convection such as SACZ. The line joining maximum values of precipitable water (shown by a dashed line in Figure 8a) agrees well with the position of SACZ. The region of high convective activity is connected to the region of more intense convection over the Amazon basin [see Figueroa et al., 1995, Figure 3]. The precipitable water values are high over the Amazon region also. In July, higher precipitable water values migrate to the northwestern part of South America. This is consistent with OLR seasonal variation over South America as discussed by Horel et al. [1989]. The seasonal variations of $P W$ over land areas are higher than those over ocean because of higher temperature variations. This is consistent with the temperature variations at 850 mbar discussed earlier. The above mentioned characteristics of water vapor over South America are also consistent with the characteristics of OLR over South America given by Janowiak et al. [1985].

Figure 9 shows the vertically integrated total water vapor transport $\left(\mathrm{kg} \mathrm{m}^{-1} \mathrm{~s}^{-1}\right)$ vector field for the four seasons, calculated using (2). The water vapor transport is mainly westward in the low latitudes because of trade winds and eastward in the high latitudes because of westerlies. During the austral summer the water vapor transport is from tropical South Atlantic into northern South America. An anticyclonic cell of water vapor transport is evident over the South Atlantic Ocean. This agrees with the characteristics of global water 

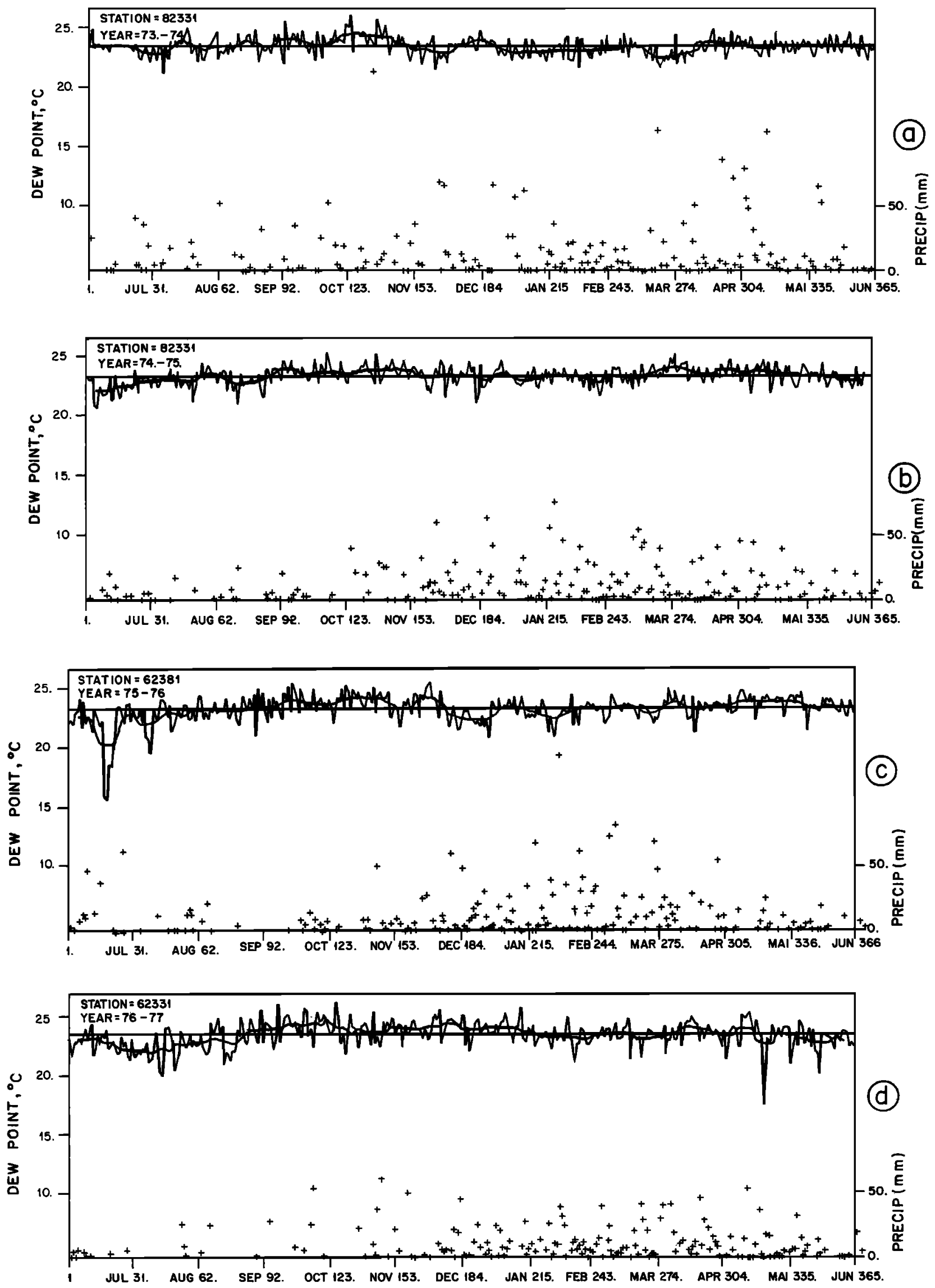

Figure 3. Same as Figure 2 but for Manaus. 

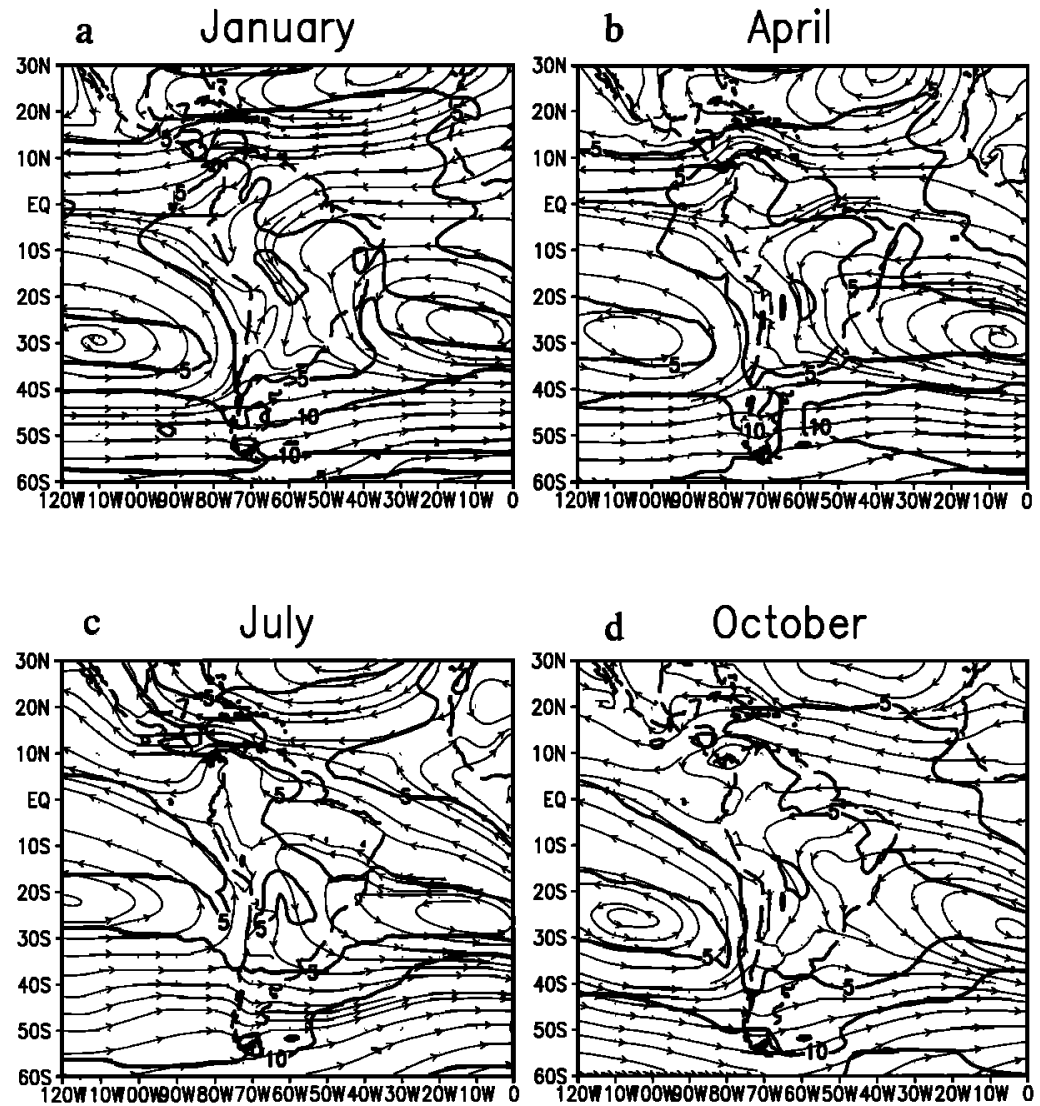

Figure 4. Mean streamlines and isotachs $\left(\mathrm{m} \mathrm{s}^{-1}\right)$ at $850 \mathrm{mbar}$ over South America: (a) January, (b) April, (c) July, and (d) October.
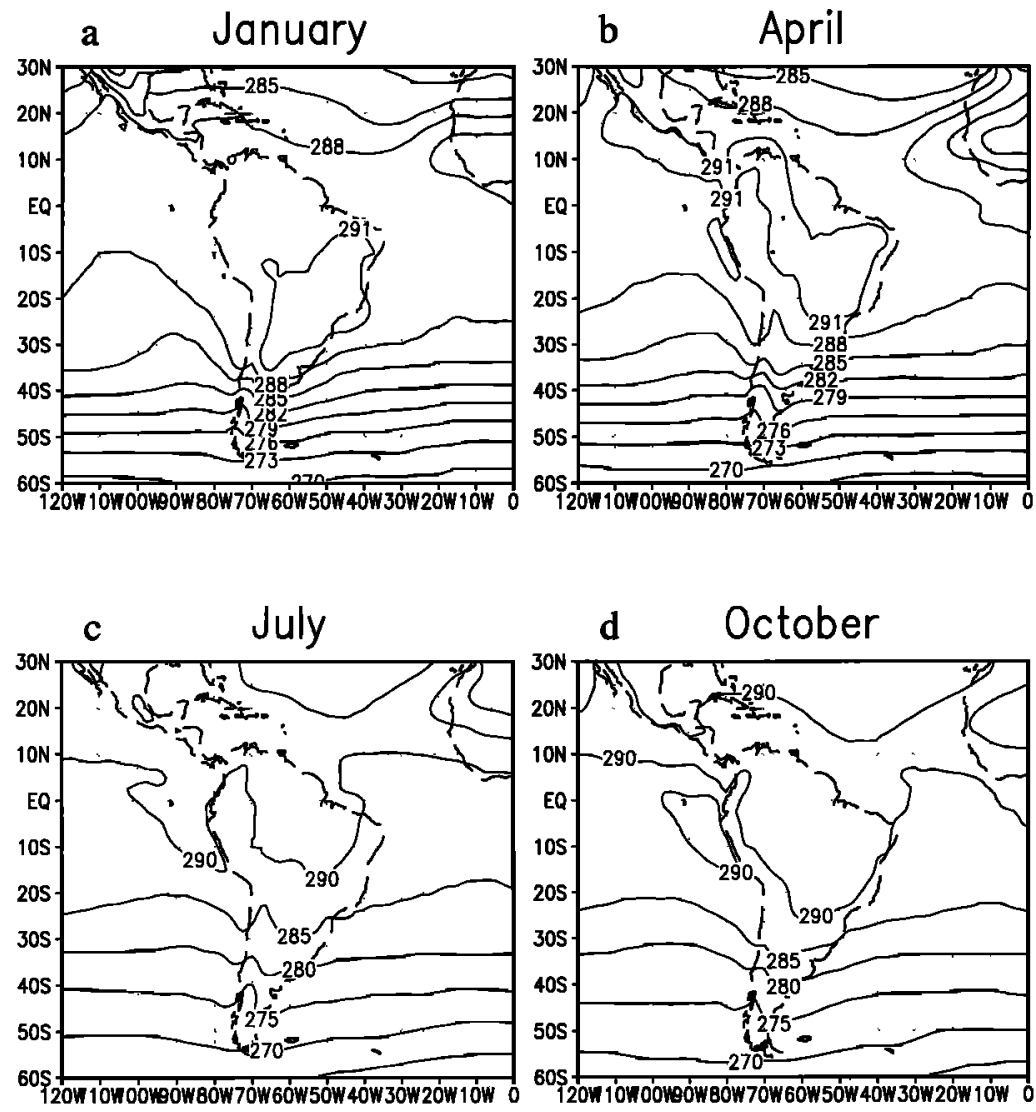

Figure 5. Distribution of isotherms (in kelvins) at 850 mbar: (a) January, (b) April, (c) July, and (d) October. 



Figure 6. Mean streamlines and isotachs $\left(\mathrm{m} \mathrm{s}^{-1}\right.$ ) at 200-mbar level: (a) January, (b) April, (c) July, and (d) October.
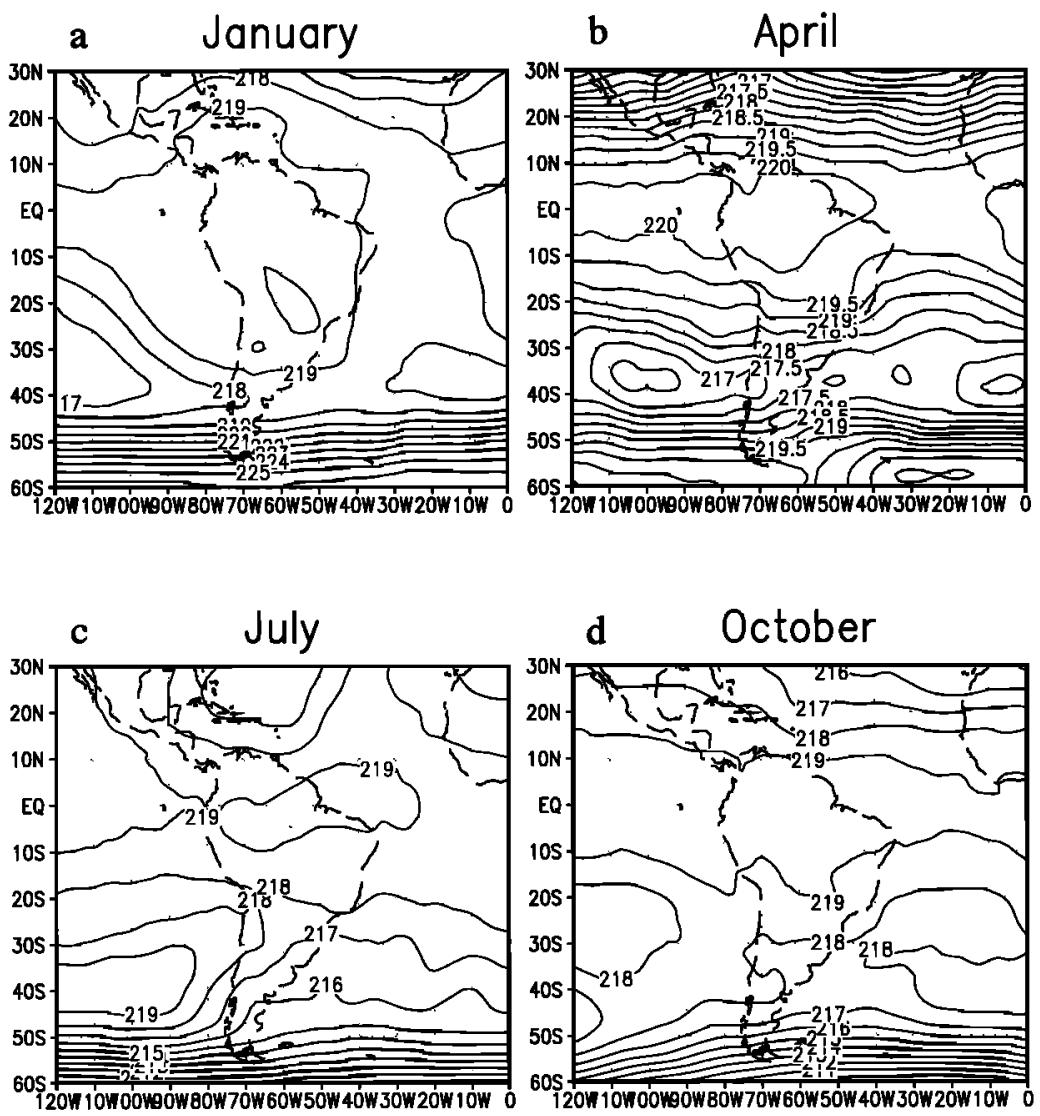

Figure 7. Distribution of isotherms (in kelvins) at 200 mbar: (a) January, (b) April, (c) July, and (d) October. 

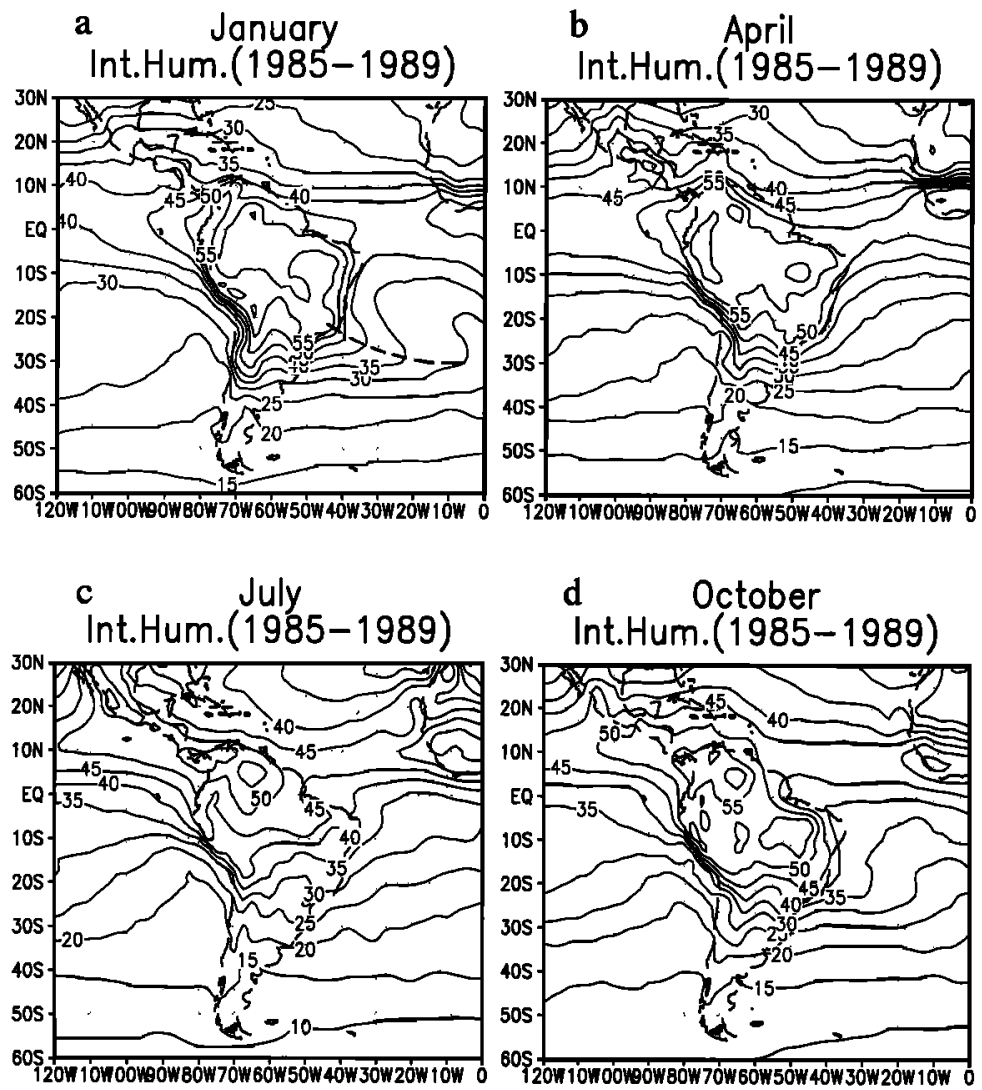

Figure 8. Precipitable water $\left(\mathrm{kg} \mathrm{m}^{-2}\right)$ : (a) January, (b) April, (c) July, and (d) October.
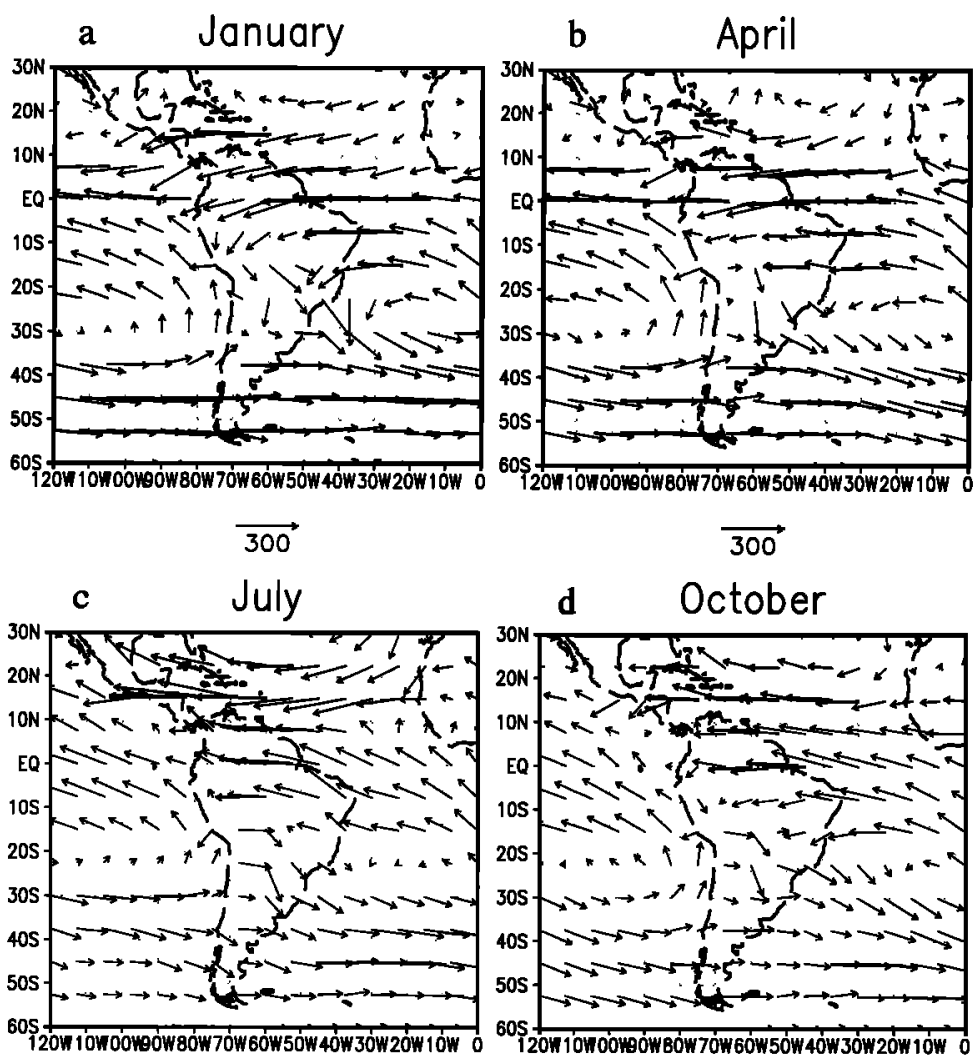

$\overrightarrow{300}$

Figure 9. Vertically integrated total water vapor transport $\left(\mathrm{kg} \mathrm{m}^{-1} \mathrm{~s}^{-1}\right)$ : (a) January, (b) April, (c) July, and (d) October. 

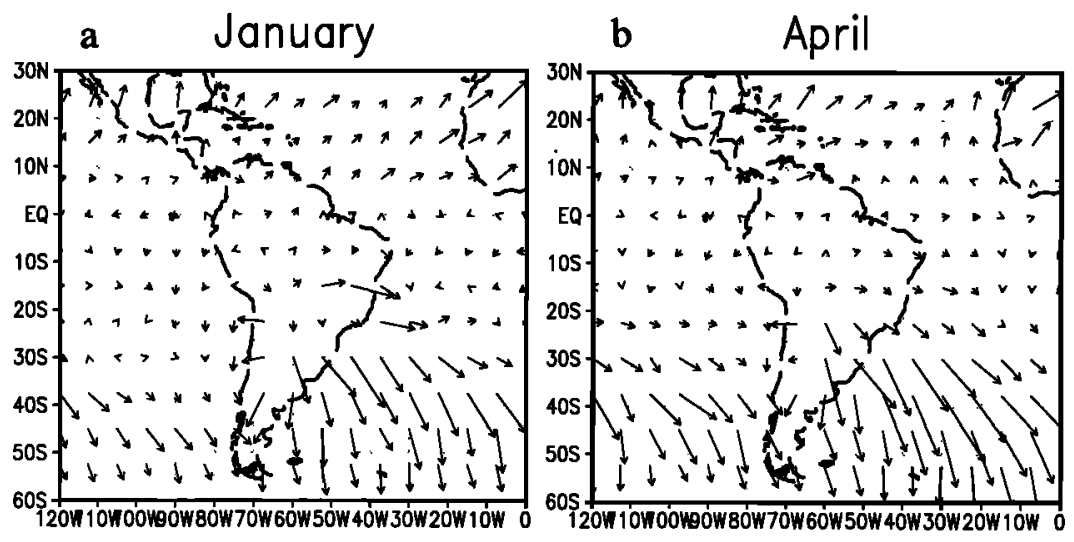

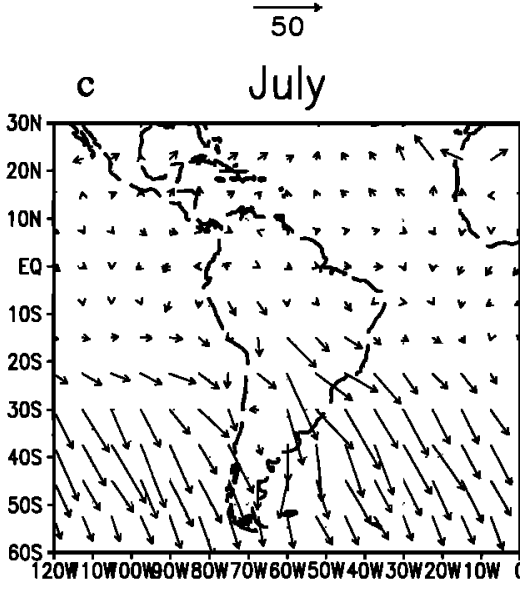

50

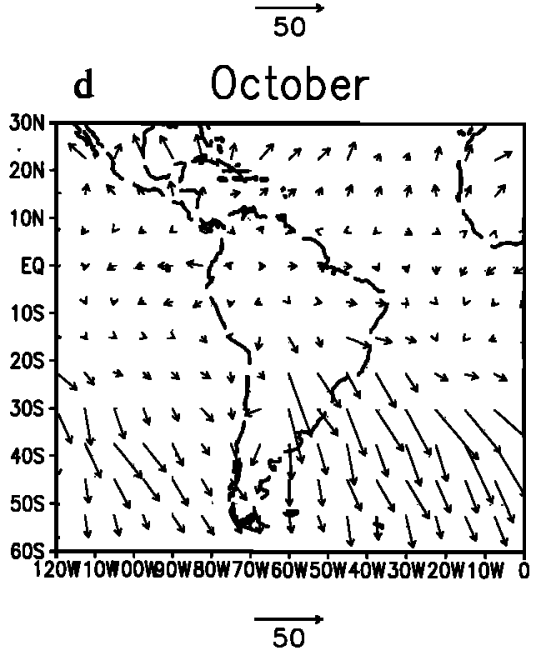

Figure 10. Water vapor transport $\left(\mathrm{kg} \mathrm{m}^{-1} \mathrm{~s}^{-1}\right)$ by transient eddies: (a) January, (b) April, (c) July, and (d) October.

vapor transport including South America given by Chen [1985] for the summer and winter. Again, we discuss in more detail than given by Chen the characteristics over South America. The important role of the South Atlantic Ocean in furnishing water vapor to the Amazon basin can be noted in Figure 9. The most relevant feature of Figure 9 for the present study is the southeastward transport of water vapor into central South America. This transport is more dominant in January than in July, and it starts becoming important in October. These features can also be inferred from the earlier studies of Marques et al. [1979a, b, 1980a, b] and James and Anderson [1984]. This corroborates the suggestion made earlier in discussing Figure 2 that the increase of moist conditions in October over central Brasil represented by Brasilia is due to the transport of water vapor from the Amazon region.

Figure 10 shows the water vapor transport by the transient eddies $\left(Q_{E}\right)$. It can be seen that this transport is generally small (note the order of magnitude, $50 \mathrm{~kg} \mathrm{~m}^{-1} \mathrm{~s}^{-1}$ ) compared to the total transport. The water vapor transport $Q_{E}$ exists mostly in the middle latitudes (south of $30^{\circ} \mathrm{S}$ ) and is southeastward. The transport by the transients is lowest in January and highest in July. This suggests that the significant water vapor transport by the transients is essentially by the transient cyclone systems.

From Figure 10 it can be inferred that in the tropics the total water vapor transport is mostly by the mean motion, since $Q_{E}$ is very small here. The water vapor transport by the mean motion (not shown here) confirms this.

Figure 11 shows the divergence of vertically integrated water vapor flux $\left(10^{-5} \mathrm{~kg} \mathrm{~m}^{-2} \mathrm{~s}^{-1}\right)$. Darker regions are associated with divergence and lighter shades represent convergence. The area of convergence over central parts of Brazil can be seen in January. The values are less reliable over the mountaineous (Andes) region. Over central Brazil the area of convergence starts reducing in April and is at a minimum in July. Over northeast Brazil, convergence of water vapor can be seen in April, which coincides with the rainfall season in this region. In July, convergence of water vapor can be seen over the northwestern part of South America. This coincides with the region of high convection in this season. Convergence of water vapor over central Brazil starts becoming important in October.

The divergence of vertically integrated water vapor flux is connected to the evapotranspiration-minus-precipitation rate $(E-P)$ through the relation (with some valid approximations)

$$
E-P=\nabla \cdot q \mathbf{v}
$$

From (4), knowing the divergence of water vapor flux and precipitation, evapotranspiration can be estimated. One region of interest to estimate, $E$, is the Amazon River basin.

From Figure 11 it can be seen that throughout the year the Amazon River basin is characterized by the convergence of around $1.5 \times 10^{-5} \mathrm{~kg} \mathrm{~m}^{-2} \mathrm{~s}^{-1}$. Taking an annual precipitation 

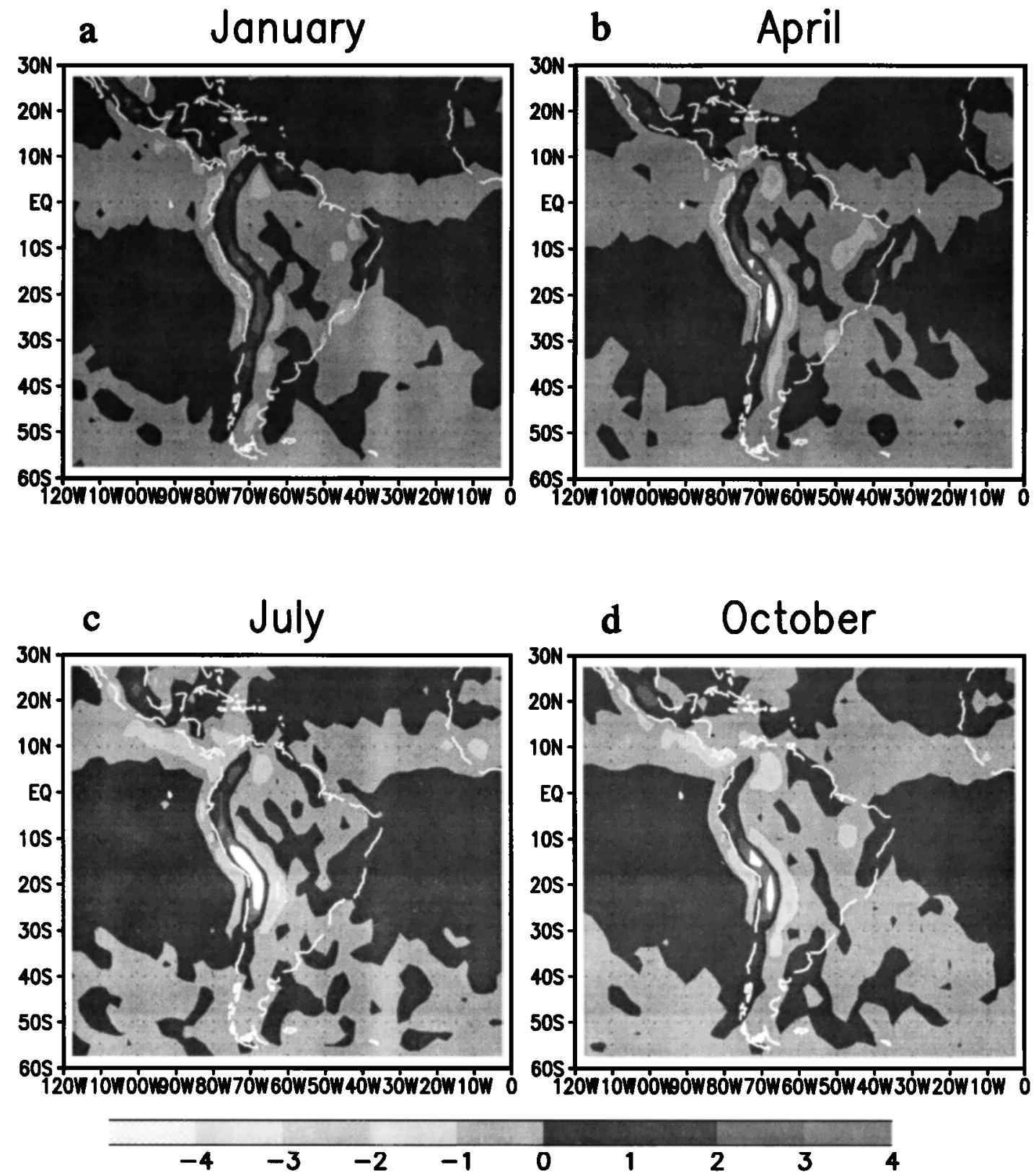

Figure 11. Divergence of vertically integrated water vapor flux $\left(10^{-5} \mathrm{~kg} \mathrm{~m}^{-2} \mathrm{~s}^{-1}\right)$ : (a) January, (b) April, (c) July, and (d) October.

of $2200 \mathrm{~mm}$, the evapotranspiration rate can be estimated to be around $4.5 \mathrm{~mm} \mathrm{~d}^{-1}$. This value agrees well with those estimated by earlier authors [see Salati and Nobre, 1991, Table 1].

\section{Summary and Concluding Remarks}

The annual variation of rainfall over Brazil is discussed. There is a large region in central Brazil which is characterized by summer rainfall. During the 6-month period of SONDJF this region receives $70 \%$ or more of the annual rainfall.

An examination of the yearly variation of dew points at the surface over Brasilia showed that the transition from dry winter conditions to a more humid atmosphere with frequent rainfall happens rather abruptly around the end of September.
Water vapor characteristics over South America were obtained using 5 years (1985-1989) of ECMWF data. A careful examination of precipitable water over South America showed broad agreement with previous studies thereby giving confidence to the present calculations. An interesting feature of the summer (January) is the maximum in precipitable water along the South Atlantic Convergence Zone. Large differences are also noted in the wind field from winter to summer, mainly at higher levels.

An analysis of vertically integrated water vapor transport and its divergence during the four seasons shows that the increase of humidity over Brasilia starting from October noted earlier is due to the incursion of moisture from the Amazon basin. The total vertically integrated water vapor transport is 
divided into that due to mean motion and that due to transient motion. In general, the transport by the transients is small in the tropics, and even in middle latitudes where it is high, it is an order of magnitude smaller than the total transport. The water vapor transport by the transients is mostly southeastward to the south of $30^{\circ} \mathrm{S}$. This is highest in July.

An estimation of the evapotranspiration over the Amazon River basin gave a value of $4.5 \mathrm{~mm} \mathrm{~d}^{-1}$ which agrees with earlier estimates.

Acknowledgments. Thanks are due to Vernon E. Kousky for suggesting improvements to an earlier version of the manuscript. Thanks are also due to the official reviewer for his comments.

\section{References}

Bengtsson, L. M., M. Kanamitsu, P. Kallberg, and S. Uppala, FGGE four dimensional data assimilation at ECMWF, Bull. Am. Meteorol. Soc., 63, 29-43, 1982.

Chen, T. C., Global water vapor flux and maintenance during FGGE, Mon. Weather Rev., 113, 1801-1819, 1985.

Chu, P. S., A contribution to the upper-air climatology of tropical South America, J. Clim., 5, 403-416, 1985.

Figueroa, S. N., P. Satyamurti, and P. L. Silva Dias, Simulations of summer circulation over South American region with an ETA coordinate model, J. Atmos. Sci., 52, 1573-1584, 1995.

Fuelberg, H. E., and J. R. Scoggins, Kinetic energy during strong jet stream activity over the eastern United States, Mon. Weather Rev., $108,69-77,1980$.

Hastenrath, S., and L. Heller, Dynamics of climatic hazards in northeast Brazil, Q. J. R. Meteorol. Soc., 103, 77-92, 1977.

Horel, J. H., A. N. Hahmann, and J. E. Geisler, An investigation of the annual cycle of convective activity over the tropical Americas, J. Clim., 2, 1388-1403, 1989.

James, I. N., and D. L. T. Anderson, The seasonal mean flow and distribution of large-scale weather systems in the southern hemisphere: The effects of moisture transports, Q. J. R. Soc., 110, 943966, 1984.

Janowiak, J. E., A. F. Krueger, P. A. Arkin, and A. Gruber, Atlas of outgoing longwave radiation derived from NOAA Satellite data, NOAA Atlas 6, 44 pp., Natl. Oceanic and Atmos. Admin., Silver Spring, Md., 1985.

Kodama, Y. M., Large-scale common features of subtropical precipitation zones (the Baiu frontal zone, the SPCZ and SACZ), I, Characteristics of subtropical frontal zones, J. Meteorol. Soc. Jpn., 70, 813-836, 1992.

Kousky, V. E., Pentad outgoing longwave radiation climatology for the South American sector, Rev. Bras. Meteorol., 3, 217-231, 1988.

Kreuels, R., K. Fraedrich, and E. Ruprecht, An aerological climatology of South America, Meteorol. Rundsch., 28, 17-24, 1975.

Kurihara, Y., Accuracy of wind aloft data and estimation of error in numerical analysis of atmospheric motions, J. Meteorol. Soc. Jpn., 39, 331-345, 1961.

Marques, J., J. M. Santos, and E. Salati, $O$ armazenamento atmosférico de vapor de água sobre a regiāo Amazônica, Acta Amazonica, 9, 715-721, 1979a.

Marques, J., J. M. Santos, and E. Salati, O campo de fluxo de vapor de água sobre a região Amazônica, Acta Amazonica, 9, 701-713, 1979b.

Marques, J., E. Salati, and J. M. Santos, Cálculo de evapotranspiração real na bacia Amazônica através do método aerológico, Acta Amazonica, 10, 357-361, 1980a.

Marques, J., E. Salati, and J. M. Santos, A divergência do campo do fluxo de vapor de água e as chuvas na região Amazônica, Acta Amazon., 10, 133-140, 1980b.

Marques, V. S., Studies on the energetics and water vapor flux in the atmosphere over Northeast Brazil (in Portuguese), doctoral thesis, 182 pp., Inst. Nac. de Pesqui. Espa., São José dos Campos, Sao Paulo, Brazil, 1981.

Marques, V. S., V. B. Rao, and L. C. B. Molion, Inter-annual and seasonal variations in the structure and energetics of the atmosphere over northeast Brazil, Tellus Ser. A, 35, 136-148, 1983.

Nishizawa, T, and $M$. Tanaka, The annual change in the tropospheric circulation and the rainfall in South America, Arch. Meteorol. Geophys. Bioklimatol., Ser. B, 33, 107-116, 1983.

Rao, V. B., and K. Hada, Characteristics of rainfall over Brazil: Annual variations and connections with the Southern Oscillation, Theor. Appl. Climatol., 42, 81-91, 1990.

Rao, V. B., M. C. de Lima, and S. H. Franchito, Seasonal and interannual variations of rainfall over eastern northeast Brazil, J. Clim., 6, 1754-1763, 1993.

Salati, E., and C. A. Nobre, Possible climatic impacts of tropical deforestation, Clim. Change, 19, 177-196, 1991.

Strang, D. M. G., Climatological analysis of rainfall normals in northeastern Brazil, Pap. NOLAE. M. 02/72, 70 pp., Cent. Téc. Aeroesp., São José dos Campos, Sao Paulo, Brazil, 1972.

Trenberth, K. E., and J. G. Olson, An evaluation and intercomparison of global analysis from the National Meteorological Center and the European Center for Medium Range Forecasts, Bull. Am. Meteorol. Soc., 69, 1047-1057, 1988.

Virji, H., A preliminary study of summertime tropospheric circulation patterns over South America estimated from cloud winds, Mon. Weather Rev., 109, 599-610, 1981.

Viswanadham, Y., N. J. M. Rao, and G. S. S. Nunes, Some studies on moisture conditions in the southern hemisphere, Tellus Ser. A, 32, 131-142, 1980.

Ward, J. H., and P. J. Smith, A kinetic energy budget over North America during the period of short synoptic wave development, Mon. Weather Rev., 104, 836-848, 1976.

I. F. A. Cavalcanti, K. Hada, and V. B. Rao, Instituto Nacional de Pesquisas Espaciais, C. P. 515, 12201-970, São José dos Campos, Sao Paulo, Brazil. (e-mail: vbrao@met.inpe.br)

(Received October 3, 1995; revised May 29, 1996; accepted June 6, 1996.) 